\title{
New Evidence on the Palaeobiology of the Eureka Sound Formation, Arctic Canada
}

\author{
MARY R. DAWSON ${ }^{1}$, ROBERT M. WEST ${ }^{2}$, PAUL RAMAEKERS ${ }^{3}$ \\ and J. HOWARD HUTCHISON ${ }^{4}$
}

\begin{abstract}
The Eureka Sound Formation, a thick sedimentary unit in the Canadian Arctic having a late Cretaceous and/or early Tertiary age, is known to contain plant fossils indicative of a continental origin of deposition and a relatively temperate climate. The Formation was selected for a palaeontological survey in ordet to determine whether it could, - as suggested by distribution of fossil vertebrates in other areas and from evidence of plate tectonics, provide evidence on terrestrial migrations between North America and Europe in the Palaeogene. Fossils of plants, invertebrates and fish were found. They indicated that large parts of the Formation are marine in origin, although other parts are continental and thus could still be interpreted as representing part of a land connection between the northern land masses.
\end{abstract}

RESUMÉ. Du nouveau sur la paléobiologie de la formation d'Eureka Sound, Canada arctique. On sait que la formation d'Eureka Sound, dans le Canada arctique, épaisse unité sédimentaire datant soit du Crétacé supérieur, soit du début du Tertiaire, soit des deux, contient des fossiles végétaux indices d'une déposition d'origine continentale et d'un climat relativement tempéré. On a choisi cette formation pour une étude paléoécologique visant à déterminer si - comme le suggèrent la distribution des fossiles de vertébrés dans d'autres régions et les données de la tectonique des socles - elle pourrait fournir des preuves de migrations terrestres entre l'Amérique du Nord et l'Europe au Paléogène. On y a trouvé des fossiles de plantes, d'invertébrés et de poissons qui indiquent que de larges portions de la formation sont d'origine marine, bien que d'autres parties soient d'origine continentale et pourraient ainsi être encore interprétées comme représentant une partie de la liaison terrestre entre les masses continentales nordiques.

РЕЗЮМЕ. Новъе данные по палеобиоловии формачии Юрика-Саунд, Канадский А рктический архипелаг. Иавестно, что повдняя меловая или ранняя третичная плотная осадочная формация Юрика-Саунд, входящая в состав Канадского Арктического архипелаг, содержит ископаемые растения, что указывает на континентальную природу осадочных материалов и на относительно умеренный климат. Палеонтологическое иуучение формации проводилось с целыо установления возможности использования ее для доказательства миграции материка между Северной Америкой и Европой в период палеогена, на что указывает слоистая тектоника и распределение ископаемых позвоночных в ряде других районов. Были найдены ископаемые растения, беспозвоночные и рыбы. Эти находки говорят о морской природе большей части формации, хотя другие ее участки континентального происхождения по-прежнему могут трактоваться как часть суши, свявывавшей когда-то северные континенты.

Recent geologic maps of the Canadian Arctic islands, made by the Geological Survey of Canada, show clearly extensive exposure areas of the Eureka Sound Formation on Ellesmere Island, with lesser exposures on Axel Heiberg Island and

1Carnegie Museum, Pittsburgh, Pennsylvania, U.S.A.

2Milwaukee Public Museum, Milwaukee, Wisconsin, U.S.A.

3Royal Ontario Museum, Toronto, Ontario, Canada.

4University of California, Berkeley, California, U.S.A. 


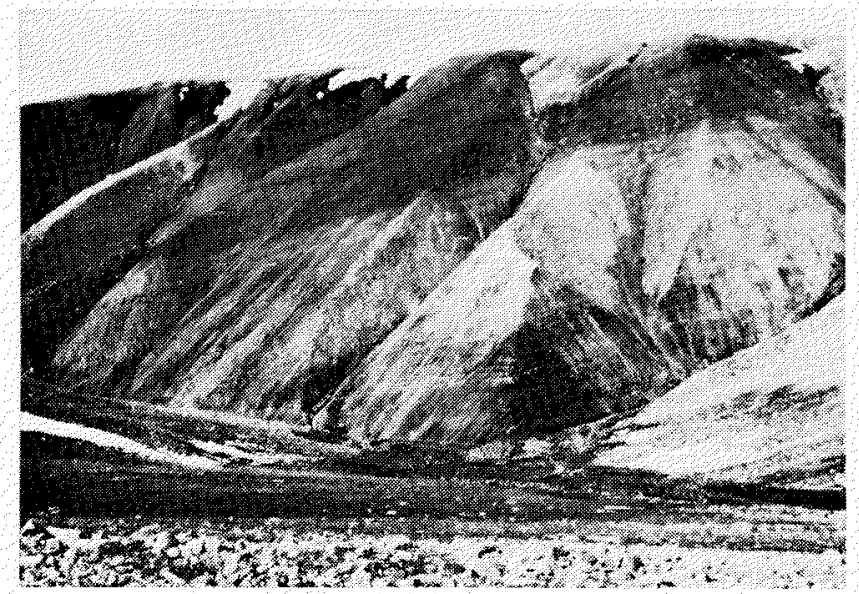

FIG. 1. Characteristic exposures of the Eureka Sound Formation near Vesle Fiord on Fosheim Peninsula, Ellesmere Island.

other islands to the southwest. This formation is a sedimentary unit of up to about $3,000 \mathrm{~m}(10,000 \mathrm{ft})$ in thickness, and composed largely of sandstone and shale, with localized development of conglomerate and coal beds (Fig. 1). On the basis of the abundance of coal, lignitic shales, silicified wood, leaf impressions, and pollen, this unit has been interpreted as representing a primarily fresh-waterfluvial environment, having more moderate climatic conditions than at present (see references to the Eureka Sound Formation and "Cenozoic Beds" in Fortier $e t$ al. 1963; Christie 1964). Plant fossils and the stratigraphic position of the Eureka Sound deposits, which overlie the late Cretaceous Kanguk Formation in many places (Tozer 1963), suggest a latest Cretaceous to Palaeogene age for this formation. The plant fossils resemble material known from West Greenland, which occurs in deposits dated on marine faunal evidence as Paleocene (Koch 1963).

The Eureka Sound Formation lies in a significant area and represents an important time when considered in connection with the current model of the development of the North Atlantic Ocean based on evidence of plate tectonics. The North Atlantic appears to have opened in a south-to-north direction, with the northern Holarctic region being the last area of physical continuity between Europe and North America (Hallam 1971). Geophysical evidence suggests that Greenland began to separate from the Eurasian plate about 60 million years ago and has been part of the North American plate since about 47 million years ago (Pitman and Talwani 1972), in middle Eocene time. These tectonic events correlate well with the Palaeogene age assigned to the Eureka Sound Formation on palaeontologic grounds. Interpretation of the Eureka Sound Formation as a fluvial unit deposited under temperate climatic conditions suggests it may have been a region for terrestrial faunal interchange between Europe and North America.

The vertebrate fossil records of Europe and North America indicate a substantial similarity, about 50 per cent at the generic level, during the early Eocene, followed by increasing endemism and only about 10 per cent generic similarity during the middle Eocene. Such reduction of similarity can be explained as a result of loss of physical contact, and hence faunal exchange, between the two land masses at the end of early Eocene time (McKenna 1972; Lehmann 1973). 
Thus, palaeobotanic evidence available from the Eureka Sound Formation itself, the plate tectonics model of the North Atlantic Ocean, and the vertebrate fossil records of Europe and North America point to the possible significance of deposits of the Eureka Sound Formation in any large-scale interpretation of Arctic history.

With these lines of evidence as a basis, an expedition was organized in 1973 by the present authors. The purpose of the investigation was to examine the Eureka Sound Formation on Ellesmere Island and to assess its fossil content. The authors hoped to find fossils that would lead to a better understanding of the Palaeogene fossil mammal assemblages of both Europe and North America, and also any palaeontological records that would enhance understanding of palaeoenvironments and of events in the area of Sverdrup Basin during the time of deposition of the Eureka Sound Formation.

The work was organized as a survey, rather than as antensive search in any one place. During six weeks of field work, seven separate camps were established (Fig. 2), movement from one to another being accomplished by aircraft.

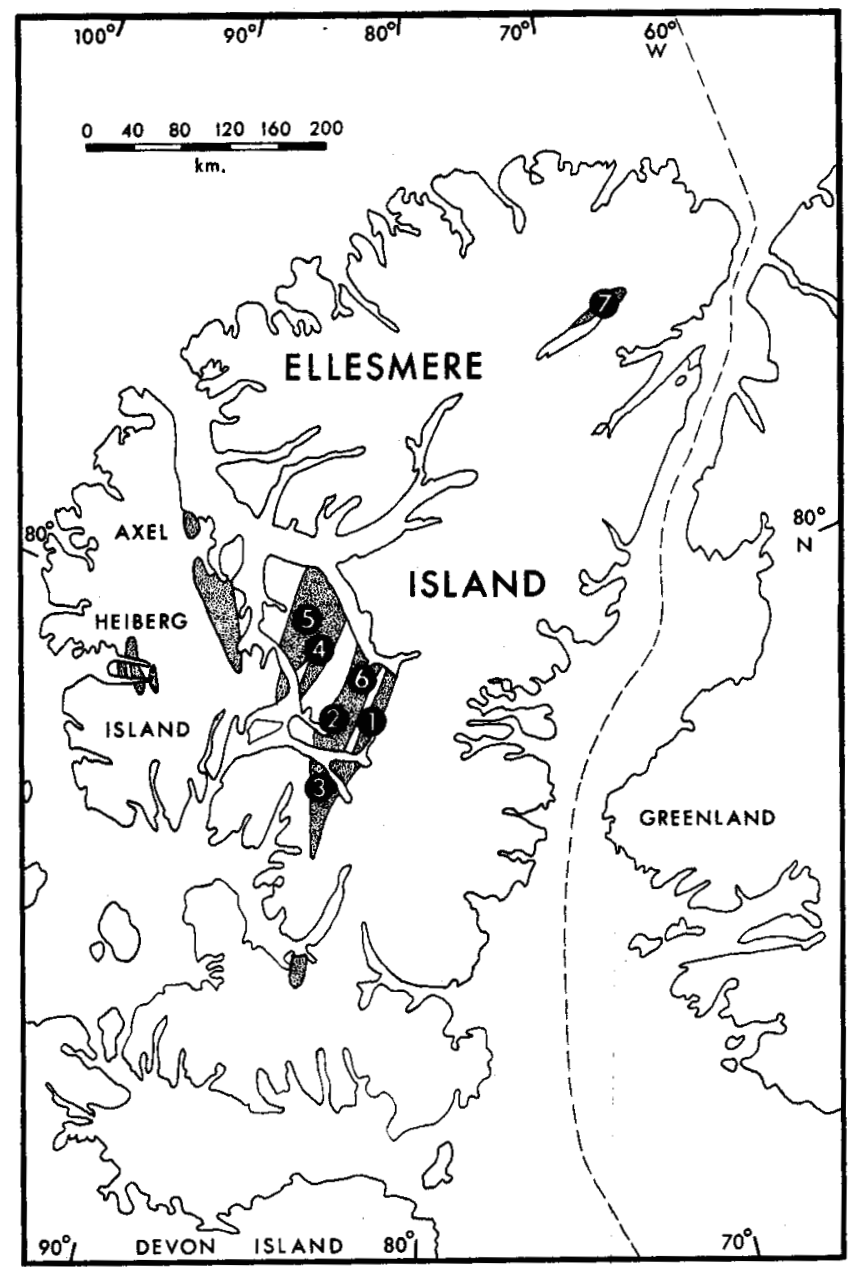

FIG. 2. Areas on

Ellesmere Island inspected by the expedition. The areas of exposure of the Eureka Sound Formation on Ellesmere and Axel Heiberg Islands are indicated by stipple, and studied areas by numbers: 1. Irene Bay;

2. Vesle Fiord;

3. Strathcona Fiord;

4. Sawtooth; 5. Clinker;

6. South Bay; 7. Lake

Hazen. 
TABLE 1. Distribution of fossils by locality

\begin{tabular}{|c|c|c|c|c|c|c|c|c|c|}
\hline \multirow[b]{2}{*}{$\begin{array}{l}\text { Locality } \\
\text { (see Fig. 2) }\end{array}$} & \multirow{2}{*}{$\begin{array}{c}\text { rtebrates } \\
\text { Fish }\end{array}$} & \multicolumn{5}{|c|}{ Invertebrates } & \multicolumn{3}{|c|}{ Plant remains } \\
\hline & & $\begin{array}{c}\text { Marine } \\
\text { molluses }\end{array}$ & $\begin{array}{l}\text { Fresh- } \\
\text { water } \\
\text { molluscs }\end{array}$ & $\begin{array}{l}\text { Fora- } \\
\text { minifera }\end{array}$ & Crinoid & $\begin{array}{c}\text { Scapho- } \\
\text { pod }\end{array}$ & Leaf & Wood & Coal \\
\hline 1. Irene Bay & & & * & & & & * & * & $*$ \\
\hline 2. Vesle Fiord & & $*$ & & * & $*$ & & & $*$ & $*$ \\
\hline 3. Strathcona & * & $*$ & $*$ & $*$ & & * & $*$ & * & * \\
\hline 4. Sawtooth & & $* *$ & $* *$ & & & & & $*$ & $*$ \\
\hline 5. Clinker & & & & & & & & $*$ & $*$ \\
\hline 6. South Bay & & $* *$ & * & & & & $*$ & $*$ & $*$ \\
\hline 7. Lake Hazen & & $* *$ & $*$ & & & & $*$ & $*$ & $*$ \\
\hline
\end{tabular}

*Taxa determined definitely

**Taxa not yet determined definitely

Exposures of the Eureka Sound Formation within reasonable walking distance of any one camp were examined.

\section{PALAEONTOLOGIC RESULTS}

Preliminary results of the palaeontologic survey at the seven areas examined (Table 1) are summarized below. Detailed descriptions of localities (field notes, maps, aerial photographs) are on file in the Section of Vertebrate Fossils, Carnegie Museum of Natural History, Pittsburgh, Pennsylvania, and the Department of Geology, Milwaukee Public Museum, Milwaukee, Wisconsin.

\section{Plant fossils}

Plant remains are present in all seven areas. Lignitic shales form prominent dark bands, and slump from these beds darkens many gentle slopes. Coals and lignitic deposits are among the most characteristic features of the Eureka Sound Formation.

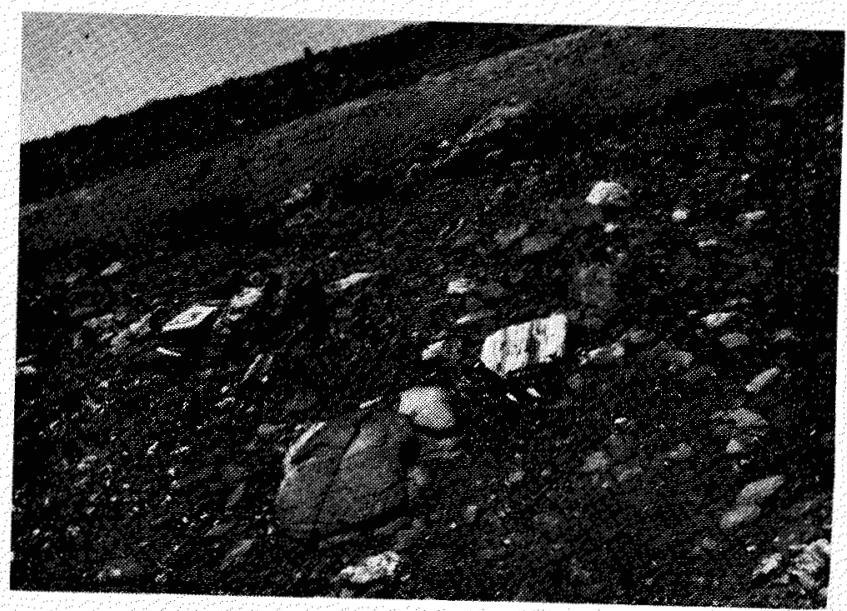

FIG. 3. Light-coloured fossilized wood on exposures of Eureka Sound Formation at the expedition's Strathcona Fiord study area. 
Fossil wood occurs frequently in the shale units (Fig. 3), and fossil wood fragments were seen in all seven areas. This wood is almost always yellow, in striking colour contrast with the black sediment. The wood is often preserved in large lumps having well-developed annual growth rings, which indicate well-marked seasons during the time of Eureka Sound deposition.

Leaves are occasionally preserved in fine grained calcareous, non-lignitic strata. Several genera have been identified previously (see identifications by W. L. Fry in Fortier 1963). The present authors collected specimens of Metasequoia from Irene Bay, Strathcona, South Bay and Lake Hazen, as well as Ginkgo from Lake Hazen and other as-yet-unidentified leaves of deciduous plants. In total, the evidence from leaves suggests a Palaeogene age for the deposits. Plant macrofossils from coal and amber documented the presence during that age of extensive forests and bogs near Lake Hazen (Kuc 1973).

\section{Invertebrate fossils}

Foraminifera were found in two areas - Vesle Fiord and Strathcona Fiord. Apart from indicating a marine, and perhaps cool, origin for the enclosing sediments, these foraminifers are of little correlative or geochronologic use, as one genus represented - Cornuspira - ranges in time from Carboniferous to Recent and the other - Cyclammina - from Cretaceous to Recent. Both genera are cosmopolitan in distribution.

Crinoid stems were also encountered at Vesle Fiord, though not in the same bed as Foraminifera. These indicate a marine environment. A broken scaphopod shell was found at Strathcona Fiord, in the same depositional sequence as, but a different level from, the foraminifers mentioned above and the otoliths mentioned below.

Other molluscs, both freshwater and marine, are relatively common. The units that yielded the foraminifers, crinoids and scaphopod also yielded fragmentary pelecypod shells, presumably of marine origin. In addition, fragments of massive clams were found in soft sandstones at Sawtooth and South Bay. The sediments there are less obviously of a marine facies.

Beds of freshwater molluscs, including both gastropods and pelecypods, are common at Strathcona Fiord, Sawtooth, South Bay and Lake Hazen. At South Bay, Lake Hazen and Irene Bay, these molluscs occur in the same strata as do leaf and stem impressions. Fossils from the Sawtooth and Strathcona areas are to be found in soft sandstones near carbonaceous deposits, but not directly associated with plant remains.

\section{Vertebrate fossils}

The only vertebrate fossils encountered during this survey were otoliths - calcareous structures formed in the otic region of fishes. Several localities in the Strathcona Fiord area yielded these structures. The otoliths represent several extinct species, and probably extinct genera, of gadoids that indicate an early Tertiary, probably Eocene, age. The modern representatives of these fish groups are inhabitants of open, marine waters. By analogy, the authors presume these deposits of the Eureka Sound Formation to have been deposited far from the strandline. 


\section{DISCUSSION}

Expanded knowledge of the palaeobiology of the Eureka Sound Formation provided by this survey necessitates some new interpretations of the geologic history of the unit. First, it is clear that much of the Formation was deposited in an openwater, marine environment. The physical nature of the sediment suggests varying depths and distances from shore. This interpretation thus constitutes a departure from most previously-held views of the Eureka Sound Formation as a fluvial unit. Secondly, occurrence of both animals and plants indicates the presence of fresh water, and probably terrestrial (paludal) environments of deposition interspersed with the marine, and perhaps lagoonal, areas. Sediments deposited in both environments are, at present, included within the Eureka Sound Formation, but the marine and fluvial facies may be mappable units worthy of formational status.

The palaeontologic results to date do not demonstrate the existence of a terrestrial vertebrate fauna during Eureka Sound time but, on the other hand, do not preclude its existence, and parts of the Eureka Sound Formation, therefore, have still to be regarded as areas of a possible intercontinental land connection.

\section{FURTHER PROSPECTS}

Results of the palaeontological survey described above illustrate how much remains to be learned about the depositional history of the Eureka Sound Formation. The recognition of diverse facies within the unit and the.abundance of fossil invertebrates bode well for future efforts at collecting. The procedures for collection employed by the present authors in prospecting for macrofossils were not oriented towards recovering microfossils, and the discovery of foraminifers suggests therefore that microfossils are abundant in parts of the Eureka Sound Formation. Molluscs are widely distributed, having been found in at least 34 localities, and undoubtedly more invertebrates could be found in other localities.

Vertebrate fossils are a somewhat different matter. Only otoliths were recovered, and no fossil bones were seen. This suggests that 1) they were overlooked; 2) appropriate facies were not examined; 3 ) there is a chemical barrier to the preservation of phosphatic materials in the Eureka Sound Formation; or 4) terrestrial vertebrates were not present. The first suggestion is weakened by the fact that tiny foraminifers were found; the others remain to be answered by further field and laboratory work.

The palaeontologic potential of the Eureka Sound Formation is great. Careful search for microfossils, both invertebrate and vertebrate, should produce assemblages which, when associated with adequate geologic data, would make a significant contribution to understanding of the Tertiary history of the Arctic.

\section{ACKNOWLEDGEMENTS}

We thank the Committee for Research and Exploration of the National Geographic Society for providing the basic financial support for our project; the Polar Continental Shelf Project for support in the form of flying time, radio equipment, fuel, and assistance in Resolute; the Carnegie Museum and the Royal Ontario Museum for contributing substantially to the costs of the project; Lawrence $C$. 
Woods, Jr. for contributing to publication costs of this paper. We are grateful to Dr. Gordon Hornaday, University of California, for identification of Foraminifera; to Dr. John Fitch, California Department of Fish and Game, for identification of the otoliths; and to Drs. R. Thorsteinsson, R. Christie and William Kerr of the Geological Survey of Canada for suggestions related to the project.

\section{REFERENCES}

CHRISTIE, R. L. 1964. Geological reconnaissance of northeastern Ellesmere Island, District of Franklin. Canada, Geological Survey, Memoir 331, pp. 51-55.

FORTIER, Y. O. et al. 1963. Geology of the north-central part of the Arctic Archipelago, Northwest Territories (Operation Franklin). Canada, Geological Survey, Memoir 320.

furlaM, A. 1971. Mesozoic geology and the opening of the North Atlantic. Journal of Geology, 79 (2): 149-50.

KOCH, B. E. 1963. Fossil plants from the Lower Paleocene of the Agatdalen (Angmârtussut) area, central Nûgssuaq Peninsula, Northwest Greenland. Meddelelser om Grønland, $172(5)$.

kUC, M. 1973. Plant macrofossils in Tertiary coal and amber from northern Lake Hazen, Ellesmere Island, N.W.T. Canada, Geological Survey, Paper 73-1, part B, p. 143.

LEHMANN, U. 1973. Zur Paläogeographie des Nordatlantiks im Tertiär. Mitteilungen, Geologisch-Paläontologisches Institut der Universität Hamburg, 42: 58-61.

MCKENNA, M. C. 1972 . Was Europe connected directly to North America prior to the Middle Eocene? Evolutionary Biology, 6: 184-7.

Prtman, w. C. and talwani, M. 1972. Sea-floor spreading in the North Atlantic. Geological Society of America Bulletin, 83: 637-8.

TOZER, E. T. 1963. Mesozoic and Tertiary stratigraphy. In: Fortier, Y. O. et al., Geology of the north-central part of the Arctic Archipelago, Northwest Territories (Operation Franklin), Canada, Geological Survey, Memoir 320, pp. 91-95. 